\title{
Teaching a seminar at Berkeley, late 1940s
}

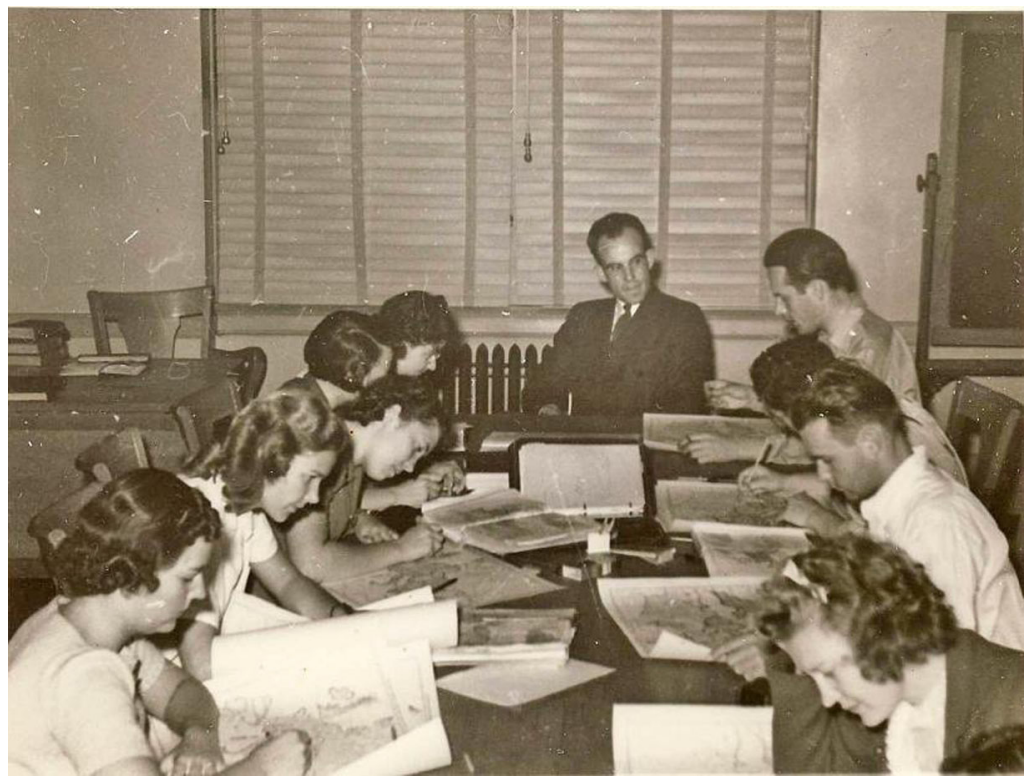

